\title{
Fibroblast Growth Factor (Fgf) 21 is a novel target gene of the Aryl Hydrocarbon Receptor (AhR)
}

\author{
Xingguo Cheng ${ }^{a}{ }^{,}$, Saurabh G. Vispute ${ }^{\mathrm{a}}$, Jie Liu ${ }^{\mathrm{b}}$, Christine Cheng $^{\mathrm{c}}$, Alexei Kharitonenkov ${ }^{\mathrm{c}}$, \\ and Curtis D. Klaassen ${ }^{b,}$ \\ aDepartment of Pharmaceutical Sciences, St. John's University, 8000 Utopia Parkway, Queens, \\ NY 11439, USA \\ ${ }^{b}$ Department of Internal Medicine, University of Kansas Medical Center, 3901 Rainbow \\ Boulevard, Kansas City, KS 66160, USA \\ 'Lilly Research Laboratories, Division of Eli Lilly and Co., Indianapolis, IN 46285, USA
}

\begin{abstract}
The toxic effects of dioxins, such as 2,3,7,8-tetrachlorodibenzo-p-dioxin (TCDD), mainly through activation of the aryl hydrocarbon receptor (AhR) are well documented. Fibroblast growth factor (Fgf) 21 plays critical roles in metabolic adaptation to fasting by increasing lipid oxidation and ketogenesis in the liver. The present study was performed to determine whether activation of the AhR induces Fgf21 expression. In mouse liver, TCDD increased Fgf21 mRNA in both doseand time-dependent manners. In addition, TCDD markedly increased Fgf21 mRNA expression in cultured mouse and human hepatocytes. Moreover, TCDD increased mRNA (in liver) and protein levels (in both liver and serum) of Fgf21 in wild-type mice, but not in AhR-null mice. Chromatin immunoprecipitation assays showed that TCDD increased AhR protein binding to the Fgf21 promoter (-105/+1 base pair). Fgf21-null mice administered $200 \mu \mathrm{g} / \mathrm{kg}$ of TCDD died within 20 days, whereas wild-type mice receiving the same treatment were still alive at one month after administration. This indicates that TCDD-induced Fgf21 expression protects against TCDD toxicity. Diethylhexylphthalate (DEHP) pretreatment attenuated TCDD-induced Fgf21 expression in mouse liver and white adipose tissue, which may explain a previous report that DEHP pretreatment decreases TCDD-induced wasting. In conclusion, Fgf21 appears to be a target gene of AhR-signaling pathway in mouse and human liver.
\end{abstract}

\section{Keywords}

Fgf21; TCDD; AhR; DEHP; liver; white adipose tissue

(C) 2014 Elsevier Inc. All rights reserved.

*Corresponding Authors: 1. Curtis D. Klaassen, Ph.D.: Department of Internal Medicine, University of Kansas Medical Center, 3901 Rainbow Boulevard, Kansas City, KS 66160, USA. curtisklaassenphd@ gmail.com. 2. Xingguo Cheng, Ph.D.: Department of Pharmaceutical Sciences, St. John's University, 8000 Utopia Parkway, Queens, NY 11439, USA. chengx@stjohns.edu.

Publisher's Disclaimer: This is a PDF file of an unedited manuscript that has been accepted for publication. As a service to our customers we are providing this early version of the manuscript. The manuscript will undergo copyediting, typesetting, and review of the resulting proof before it is published in its final citable form. Please note that during the production process errors may be discovered which could affect the content, and all legal disclaimers that apply to the journal pertain. 


\section{Introduction}

For decades, researchers have sought to characterize the molecular mechanisms by which polychlorinated dibenzodioxins, including 2, 3, 7, 8-tetrachlorodibenzo-p-dioxin (TCDD), cause concomitant toxicities, such as the wasting syndrome, thyroid disorders, hepatotoxicity, teratogenesis, and carcinogenicity. In general, TCDD binds to the aryl hydrocarbon receptor (AhR), which leads to dissociation of the AhR from cytoplasmic proteins. The ligand-bound AhR then translocates into the nucleus and heterodimerizes with the AhR nuclear translocator (Arnt) (Whitlock, 1990; McLane and Whitlock, 1994). The AhR/Arnt heterodimer binds to AhR response elements (AhR-REs) in the promoter region of target genes, such as cytochrome p450 enzyme 1a1 (Cyp1a1), and induces a number of its toxicities, such as birth defects, body weight loss, immune system suppression, and cancers.

Fgf21 has recently been recognized as a metabolic regulator, with a possible therapeutic application for the metabolic syndrome. Fgf21 is preferentially expressed in liver (Nishimura et al., 2000; Fon Tacer et al., 2010; Adams et al., 2013), but functions as an endocrine hormone. Fgf21 enhances glucose uptake in adipocytes, corrects hyperglycemia, hyperinsulinemia, dyslipidemia, and $\beta$-cell dysfunction, and protects animals from dietinduced obesity when injected to rodents or over-expressed in transgenic mice (Kharitonenkov et al., 2005; Wente et al., 2006). Administration of Fgf21 to diabetic monkeys decreases fasting concentrations of serum glucose, triglycerides, total cholesterol, low-density lipoprotein cholesterol and insulin, but increases high-density lipoprotein cholesterol levels, and causes moderate but significant weight loss (Kharitonenkov et al., 2007). In mouse liver, Fgf21 increases lipid oxidation and ketogenesis, but decreases gluconeogenesis at the gene expression level (Badman et al., 2007; Inagaki et al., 2007; Beenken and Mohammadi, 2009; Potthoff et al., 2009). In contrast, other research groups suggested that Fgf21 reduces hepatic glucose output (Berglund et al., 2009; Xu et al., 2009). In addition, Fgf21 increases growth-hormone resistance and thus inhibits mouse growth in Fgf21-transgenic mice and by administration of recombinant Fgf21 protein, via inhibiting the activation of signal transducer and activator of transcription 5, a major mediator of growth-hormone actions, and inducing hepatic expression of insulin-like growth factor-1 binding protein 1 and suppressor of cytokine signaling 2 (Inagaki et al., 2008). Activation of multiple signaling pathways, including peroxisome proliferator-activated receptors alpha (PPARa) by fasting, Wy-14643, and ketogenic diets in mouse liver and human primary hepatocytes (Badman et al., 2007; Inagaki et al., 2007; Lundasen et al., 2007), PPAR $\gamma$ in mouse white adipose tissue and mature 3T3-L1 adipocytes (Muise et al., 2008; Wang et al., 2008), and Akt signaling pathways in mouse skeletal muscle and cultured skeletal muscle cells (Izumiya et al., 2008), leads to induction of Fgf21 expression (Adams and Kharitonenkov, 2012).

TCDD induces some effects similarly as Fgf21 does in rodents, such as body weight loss, growth-hormone signaling inhibition (Croutch et al., 2005; Inagaki et al., 2008), and increased hepatic lipid oxidation and ketogenesis (Lakshman et al., 1991; IARC, 1997; Badman et al., 2007; Inagaki et al., 2007). However, it is not known whether TCDD regulates these effects through up-regulating Fgf21. Therefore, the present study was 
performed to determine whether TCDD regulates Fgf21 expression, and if so, then to determine the underlying mechanism.

\section{Materials and Methods}

\section{Materials}

Micro- $O$-protect was obtained from Roche Diagnostics (Indianapolis, IN). Formaldehyde, 4morpholinepropanesulfonic acid, and sodium citrate were purchased from Fisher (Fairlawn, NJ). Chloroform, agarose, and ethidium bromide were purchased from AMRESCO Inc. (Solon, OH). 2,3,7,8-Tetrachlorodibenzo-p-dioxin (TCDD) was a gift from Dr. Karl Rozman (University of Kansas Medical Center, KS). All other chemicals, unless otherwise indicated, were purchased from Sigma-Aldrich Co. (St. Louis, MO). Chromatin immunoprecipitation (ChIP) assay kit (\#17-295) was purchased from Millipore (Billerica, MA).

Anti-AhR polyclonal antibody (SA-210) (Enzo Life Sciences Inc, Farmingdale, NY), IgG and $\beta$-actin antibodies (Abcam Inc, Cambridge, MA) and goat anti-rabbit IgG horseradish peroxidase-linked secondary antibody (Sigma-Aldrich Co., St. Louis. MO) were all obtained commercially.

\section{Animals and treatment}

Eight-week-old adult male C57BL/6 mice were purchased from Jackson Laboratories (Bar Harbor, ME), and housed according to the Association for Assessment and Accreditation of Laboratory Animal Care International. Groups of five mice were administered one of the following chemicals once daily for 4 days: TCDD ( $40 \mu \mathrm{g} / \mathrm{kg}$, ip in corn oil) and $\beta$ naphthoflavone (BNF, $200 \mathrm{mg} / \mathrm{kg}$, ip in corn oil). Control groups received corn oil by ip. All injections were administered in a volume of $10 \mathrm{ml} / \mathrm{kg}$. Livers and white adipose tissues were removed on day 5 , snap-frozen in liquid nitrogen, and stored at $-80^{\circ} \mathrm{C}$.

Dose- and time-response study-Groups of three adult male C57BL/6J mice were administered TCDD ip once at doses of $0.1,1,10,50,100$, and $200 \mu \mathrm{g} / \mathrm{kg}$. The control group received corn oil intraperitoneally. After $0.25,1,7,14$, and 21 day(s), livers were collected, snap-frozen in liquid nitrogen, and stored at $-80^{\circ} \mathrm{C}$. The livers were collected between 8:00 AM to 9:30 AM.

Diethylhexylphthalate (DEHP)-TCDD co-treatment study_Eight-week-old adult male C57BL/6 mice were separated into 5 treatment groups ( $n=5 /$ treatment group). Group- 1 mice were given a single ip administration of TCDD at $40 \mu \mathrm{g} / \mathrm{kg}$. Group- 2 mice were given DEHP po once daily for 4 days at $1000 \mathrm{mg} / \mathrm{kg}$. Group-3 mice were pretreated with DEHP (po at $1000 \mathrm{mg} / \mathrm{kg}$ ); $24 \mathrm{hrs}$ later, these mice were then treated with TCDD (a single administration at $40 \mu \mathrm{g} / \mathrm{kg}$ ) and DEHP (once daily for another 4 days at $1000 \mathrm{mg} / \mathrm{kg}$ ). Two control groups (corn oil by ip and corn oil by po) were used. No statistical difference was observed between these two control groups, and thus the two groups were combined as a single control group. Mouse livers and WAT were collected 4 days after treatment. 
Male AhR-null mice (>99\% congenic for C57BL/6 background) from the Jackson laboratories (stock \#002831) have been described previously (Schmidt et al., 1996). Wildtype (WT) C57BL/6 and AhR-null mice ( $\mathrm{n}=5$ /group) were administered ip once daily for 4 days with either corn oil $(5 \mathrm{ml} / \mathrm{kg})$ or TCDD $(40 \mu \mathrm{g} / \mathrm{kg})$ in corn oil. Livers were collected on day 5 , frozen in liquid nitrogen, and stored at $-80^{\circ} \mathrm{C}$.

\section{Total RNA isolation}

Total RNA was isolated using RNA-Bee reagent (Fisher, Fairlawn, NJ) according to the manufacturer's instructions. RNA pellets were re-suspended in diethyl pyrocarbonatetreated deionized water. Total RNA concentrations were quantified spectrophotometrically at $260 \mathrm{~nm}$.

\section{Messenger RNA bDNA assays}

Reagents required for RNA analysis (i.e., lysis buffer, amplifier/label probe dilution buffer, and substrate solution) were supplied in the Quantigene ${ }^{\circledR}$ bDNA signal amplification kit (Panomics Inc., Fremont, CA). The mRNA of each gene was quantified according to the manufacturer's instructions. The probe sets of mouse AhR and Cyp1a1 have been reported previously (Cheng et al., 2005; Petrick and Klaassen, 2007). The probeset of mouse Fgf21 is shown in Table 1.

\section{Protein extraction}

Cytoplasmic protein from mouse livers was extracted using NE-PER Nuclear and Cytoplasmic Extraction Reagent kit (Pierce Biotechnology, Inc., Rockford, IL), according to the manufacturer's instructions.

\section{Western blots}

Protein samples mixed with sample loading buffer ( $40 \mu \mathrm{g}$ protein/lane) were boiled and loaded on a 4-20\% continuous SDS-polyacrylamide gel. Following electrophoresis, proteins in the gel were electro-transferred to a nitrocellulose membrane for $4.5 \mathrm{hrs}$ at 30 volts at room temperature. Membranes were blocked for five hrs at room temperature with $3 \%$ BSA in Tris-buffered saline containing $0.1 \%$ Tween-20 (TBS-T). Blots were then incubated overnight with anti-human Fgf21 antibody that cross-reacts with mouse Fgf21 at $4{ }^{\circ} \mathrm{C}$ (Izumiya et al., 2008). $\beta$-actin antibody was used as a loading control. After thorough washing (three 20-min washes with excess TBS-T), blots were incubated with goat antirabbit IgG horseradish peroxidase-linked secondary antibody (1:5,000 dilution with 5\% nonfat milk in TBS-T) for $1 \mathrm{hr}$. Blots were washed again. Immunoreactive bands were detected with an enhanced chemical luminescence (ECL) kit (Pierce Biotechnology Inc., Rockford, IL). Fgf21 and $\beta$-actin protein bands were visualized by exposure to Fuji Medical X-Ray film. The protein band intensities on the films were quantified with Gel-Pro 3.1 image analysis software (MediaCybernetics, Silver Spring, MD). 


\section{Quantification of serum Fgf21 protein}

Twenty $\mu \mathrm{L}$ of mouse serum samples were processed for quantification of serum Fgf21 levels by using Millipore's Rat/Mouse FGF21 Elisa kit (Billerica, MA) per the manufacturer's instructions.

\section{Chromatin Immunoprecipitation (ChIP) assays}

Preparation of liver samples for ChIP assays was described previously (Ding et al., 2006), with minor modifications. Briefly, approximately $50 \mathrm{mg}$ of mouse liver was passed through an 18-gauge needle, then a 20-gauge needle in $1 \mathrm{ml}$ of PBS supplemented with PMSF and a protease inhibitor cocktail (Roche Diagnostics, Indianapolis, IN) to make the tissue suspension. DNA-protein cross-linking was performed by incubating liver tissue suspension with formaldehyde at a final concentration of $1 \%$ for about $35 \mathrm{~min}$ at room temperature with gentle shaking. Glycine was added to $0.125 \mathrm{M}$ to terminate the cross-linking reaction. ChIP assays were performed using a ChIP assay kit (Upstate, Lake Placid, NY) according to the manufacturer's instructions. Six $\mu \mathrm{g}$ of IgG antibody or $6 \mu \mathrm{g}$ anti-AhR antibody were used for immunoprecipitation. Precipitated DNAs were purified by using a MinElute ${ }^{\circledR}$ PCR purification kit (\#28004) (Qiagen Sciences, MA). Purified DNA was dissolved in $30 \mu \mathrm{l}$ of water. Three $\mu \mathrm{l}$ of DNA solution was used for the Quantitative Real-time PCR reaction. The following primers were used: forward primer (GAATTCAGGTTCCTGCCAAGT), reverse primer (GGTGAACGCAGAAATACCAGAAT). Each PCR reaction mix contained: $5 \mu \mathrm{l}$ of Applied Biosystems SYBR ${ }^{\circledR}$ green PCR master mix, $0.4 \mu$ of $10 \mu \mathrm{M}$ forward and reverse primer mix, $1.6 \mu \mathrm{l}$ RNAse-free $\mathrm{H}_{2} \mathrm{O}$, and $3 \mu \mathrm{l}$ of DNA samples. Fluorescence was quantified using an Applied Biosystems 7900 Real Time PCR System under the following conditions: $50^{\circ} \mathrm{C}$ for $2 \mathrm{~min} ; 95^{\circ} \mathrm{C}$ for $10 \mathrm{~min} ;\left(95^{\circ} \mathrm{C}\right.$ for $15 \mathrm{sec} ; 60^{\circ} \mathrm{C}$ for $\left.1 \mathrm{~min}\right) \times 40$ cycles; dissociation stage: $95^{\circ} \mathrm{C}$ for $15 \mathrm{sec} ; 60^{\circ} \mathrm{C}$ for $30 \mathrm{sec} ; 95^{\circ} \mathrm{C}$ for $15 \mathrm{sec}$.

\section{Cell culture and TCDD treatment}

Mouse Hepa1c1c7 cells were grown in Alpha minimum essential medium (Mediatech, Inc; Manassas, VA) containing 10\% fetal bovine serum (Atlanta Biologicals, Flowery Branch, $\mathrm{GA})$ at $37^{\circ} \mathrm{C}, 5 \% \mathrm{CO}_{2}$. Human Hep3B cells were grown in Dulbecco's Modified Eagle Media (Mediatech, Inc; Manassas, VA) containing 10\% fetal bovine serum (Atlanta Biologicals, Flowery Branch, GA) at $37{ }^{\circ} \mathrm{C}, 5 \% \mathrm{CO}_{2}$. Both cells were cultured in 12-well plates and allowed to grow to 90-95\% confluence. Cells, in triplicate, were treated with either dimethyl sulfoxide (DMSO) or 10nM TCDD. Sixteen hours later, cells were harvested and total RNA was extracted using Ribozol RNA extraction reagent (Amresco, Solan, $\mathrm{OH}$ ).

\section{Mouse survival studies after TCDD treatment}

Breeding pairs of Fgf21-null mice and corresponding wild-type mice were kindly provided by Dr. Steven Kliewer (UT Southwestern Medical Center, Dallas, TX), and housed according to the Association for Assessment and Accreditation of Laboratory Animal Care International. Adult male wild-type mice (approximately 8-weeks of age) and age-matched male Fgf21-null mice were given a single ip administration of corn oil or TCDD $(200 \mu \mathrm{g} / \mathrm{kg})$ $(\mathrm{n}=4-7 /$ treatment). Mouse survival was monitored daily. 


\section{Statistical Analysis}

Data were expressed as Mean \pm S.E. Data were analyzed by one-way analysis of variance, followed by Duncan's post-hoc test using Statistica software (StatSoft Inc., Tulsa, OK). Data of two-sample comparisons were analyzed by student's T-test. Statistical significance was considered at $\mathrm{p}<0.05$.

\section{Results}

\section{Regulation of Fgf21 mRNA expression in mouse liver and cultured mouse and human hepatocytes by AhR activators TCDD and/or $\beta$-naphthoflavone (BNF)}

TCDD and BNF are two well-known AhR activators. As shown in the top panel of Fig. 1, four-day consecutive treatment of TCDD $(40 \mu \mathrm{g} / \mathrm{kg})$ and BNF $(200 \mathrm{mg} / \mathrm{kg})$ increased Fgf21 mRNA 11.2- and 5.7-fold in mouse liver, respectively. As depicted in the bottom panel of Fig. 1, 16-hour treatment of 10nM TCDD increased Fgf21 mRNA expression more than 150- and 230-fold in human Hep3B and mouse Hepa1c1c7 cells, respectively.

\section{Dose- and time-response of Fgf21 induction by TCDD}

A chemical produces effects dependent on both the dose and the time of exposure. After a long-term or a higher-dose exposure, a chemical could trigger a secondary effect following the primary or direct response. To determine whether TCDD directly regulates Fgf 21 expression, dose- and time-response studies of Fgf21 regulation by TCDD were performed. As depicted in Fig. 2, after single doses of $10 \mu \mathrm{g} / \mathrm{kg}$ or less of TCDD, induction of Fgf21 mRNA expression was most prominent at $6 \mathrm{hrs}$. In contrast, at doses higher than $50 \mu \mathrm{g} / \mathrm{kg}$, TCDD time-dependently increased Fgf 21 mRNA, which reached a maximum 14 days later, and declined thereafter. The rapid induction of Fgf21 by TCDD suggests that TCDD directly induced Fgf21 mRNA expression.

\section{Regulation of Fgf21 mRNA and protein by TCDD in wild-type and AhR-null mouse livers}

AhR-null mice were used to determine whether up-regulation of Fgf21 expression by TCDD is dependent on AhR activation (Tijet et al., 2006). As shown in Fig. 3a, removal of the AhR protein in AhR-null mice increased constitutive mRNA levels of Fgf21. In addition, TCDD

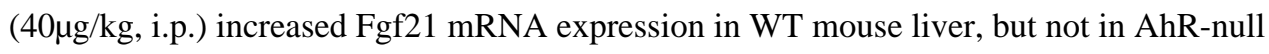
mouse. Thus, up-regulation of Fgf21 mRNA in mouse liver by TCDD is AhR-dependent.

TCDD (40 $\mu \mathrm{g} / \mathrm{kg}$, i.p.) increased Fgf21 protein $140 \%$ in WT mouse livers, but decreased it 65\% in AhR-null mouse livers (Fig. 3b). Liver-derived Fgf21 can function as an endocrine hormone (Kharitonenkov et al., 2005; Inagaki et al., 2007). Then, the effect of TCDD on the regulation of serum concentrations of Fgf21 protein was also examined. As shown in Fig. $3 c$, TCDD (40 $\mu \mathrm{g} / \mathrm{kg}$, i.p.) increased serum Fgf21 protein concentrations approximately 37fold in WT mice, but not in AhR-null mice. Therefore, TCDD increased liver and serum Fgf21 protein in an AhR-dependent manner. 


\section{Analysis of AhR protein binding to the Fgf21 promoter following TCDD treatment by ChIP assays}

In silico analysis of $2-\mathrm{kb}$ of the mouse Fgf21 gene promoter identified a putative AhRresponse element (AhR-RE) (-105/+1 bp). To determine whether the AhR binds to this putative AhR-RE in the Fgf21 promoter in vivo, ChIP assays were performed using extracts isolated from mouse liver. IgG or anti-AhR antibody was used to precipitate DNA from liver extracts of mice treated with either vehicle (corn oil) or TCDD. Then, quantitative real-time PCR was conducted to determine whether AhR binds to putative AhR-RE in the promoter

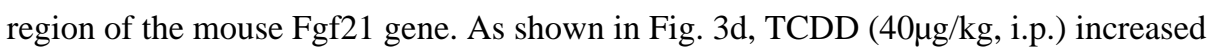
binding of AhR protein to the $-105 /+1$ fragment of Fgf 21 gene promoter by 4 -fold compared to control mice.

\section{Regulation of Fgf21 by TCDD in white adipose tissue (WAT)}

Other than liver, Fgf21 is also expressed in adipose tissue (Muise et al., 2008). Then, the regulation of Cyp1a1 and Fgf21 mRNA expression by TCDD was also determined in WAT.

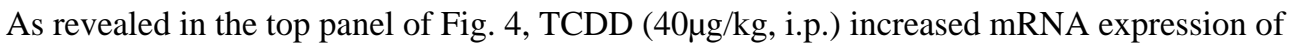
Cyp1a1 and Fgf21 in both mouse liver and WAT. Specifically, in mouse WAT, TCDD induced Fgf21 mRNA approximately 3-fold.

Because the actions of TCDD are largely mediated by activation of the AhR-signaling pathway, we next determined whether AhR is expressed in mouse WAT. As shown in the bottom panel of Fig. 4, the AhR appears to be expressed at a relatively high level in mouse WAT, compared to that in mouse liver. Taken together, TCDD induced Fgf21 mRNA expression in mouse WAT is most likely through AhR activation.

\section{Induction of Fgf21 by TCDD is attenuated by DEHP}

A previous study showed that TCDD-induced fatty liver, hyperlipidemia and body-weight loss was antagonized by the pretreatment of rodents with DEHP, followed by daily exposure to DEHP after TCDD treatment (Tomaszewski et al., 1988). However, the mechanism responsible for this antagonism phenomenon is not known. Because Fgf21 has important role in glucose and lipid metabolism, it is of interest to investigate whether DEHP modifies TCDD-induced Fgf21 mRNA expression in mouse liver and WAT. As depicted in the top panel of Fig. 5, DEHP treatment alone decreased Fgf21 mRNA expression 70\% in mouse liver. DEHP pretreatment attenuated TCDD-induced Fgf 21 mRNA approximately $63 \%$ in mouse liver. In mouse WAT, as depicted in the bottom panel of Fig. 5, TCDD $(40 \mu \mathrm{g} / \mathrm{kg}$, i.p.) treatment induced Fgf21 mRNA expression approximately 3-fold. DEHP pretreatment abolished the Fgf21 mRNA induction by TCDD.

\section{Impact of Fgf21 on TCDD-induced lethality in wild-type and Fgf21-null mice}

As shown in Fig. 6, control-treated wild-type mice, TCDD-treated wild-type mice, and control-treated Fgf21-null mice all survived one month after initial treatment. In contrast, all TCDD-treated Fgf21-null mice died within 20 days after treatment. 


\section{Discussion}

The present studies demonstrated that Fgf21 is a novel target gene of AhR. The rapid induction of Fgf21 by low doses of TCDD (Fig. 2), in combination with the direct binding of the AhR to the Fgf21 promoter after TCDD treatment (Fig. 3d), strongly suggests that Fgf21 is a direct transcriptional target of AhR. In addition, we showed that TCDD-induced Fgf21 expression plays a protective effect by antagonizing TCDD-induced lethality. Moreover, TCDD induced Fgf21 expression in both human and mouse hepatocytes (the bottom panel of Fig. 1). This finding emphasizes the human relevance of Fgf21 induction by AhR activation. The human FGF21 is largely identical to mouse Fgf21 with almost 75\% homology (Nishimura et al., 2000). Both mouse and human Fgf21/FGF21 can be upregulated by PPARa activators (Inagaki et al., 2007). However, compared to mouse Fgf21, human FGF21 expression is less sensitive to fasting/starvation (Galman et al., 2008).

Moreover, putative AhR-REs are present in both human and mouse FGF21/Fgf21 promoter. Our ChIP assays indicated that TCDD enhanced the binding of AhR protein to the $-105 /+1$ bp region of the mouse Fgf21 promoter (Fig. 3d). In addition, we also showed that TCDD did not alter the binding of IgG antibody to the $-105 /+1$ bp element of Fgf 21 gene (data not shown). In this region, a putative AhR-RE

(CTCCTGACGCGTGATATTTGACACA; consensus AhR-RE sequence is underlined) is located. We also screened 4kb promoter sequence of human FGF21 gene. Two putative AhR-REs (position -370 bp upstream of transcription start site, TTTCTCTTGTTCTGCGTGATCTGCATAGA; Position $-3150 \mathrm{bp}$ upstream of transcription start site, GCATCATTGCGTGGACCAGG; AhR-RE consensus sequences are underlined) were revealed. Therefore, AhR activation may increase FGF21/Fgf21 expression in both mice and humans.

Many environmental chemicals, including polychlorinated dibenzo-p-dioxins, polychlorinated dibenzofurans (IARC, 1997), aromatic hydrocarbons, dietary polyphenols (Amakura et al., 2008), as well as antitumor drugs such as sulforaphane (Anwar-Mohamed and El-Kadi, 2009) and aminoflavone (Loaiza-Perez et al., 2004) can activate the AhR. Because Fgf21 plays important roles in the glucose and lipid metabolism, the impact of these chemicals on Fgf21 expression may contribute to their pharmaco/toxicodynamics.

The present study demonstrated that AhR activation induced Fgf21 expression in both mouse liver and WAT (Figs. 4 and 5). In contrast, PPAR isoforms differentially regulated Fgf21 expression in the liver and WAT (Badman et al., 2007; Inagaki et al., 2007; Lundasen et al., 2007; Moyers et al., 2007; Suzuki et al., 2008; Wang et al., 2008). For example, PPARa activation by fasting, Wy-14643 administration, and feeding a ketogenic-diet can only induce Fgf21 expression in the liver; whereas PPAR $\gamma$ activation can only induce Fgf21 expression in WAT.

Despite the many reported detrimental effects of TCDD and AhR activation, low levels of AhR activation have been shown to have certain beneficial effects, such as chemoprevention, stimulation of the immune system, and longevity in experimental animals (Kociba et al., 1978; Fried et al., 2007). As Fgf21 is a promising therapeutic candidate to 
treat metabolic syndrome, AhR activation-induced Fgf21 may contribute to beneficial effects of certain dietary polyphenols and very low doses of TCDD. In addition, as suggested in Fig. 6, TCDD-induced Fgf21 expression plays a protective effect by improving the survival rate followed by TCDD treatment.

A previous study showed that pretreatment of rodents with DEHP attenuates TCDD-induced toxicities (Tomaszewski et al., 1988). These toxicities, such as body weight loss and interference of growth-hormone signaling, are similar to the Fgf21-induced symptoms observed in Fgf21-transgenic mouse model or following the administration of recombinant Fgf21 protein (Kharitonenkov et al., 2007; Inagaki et al., 2008). Thus, one plausible explanation for the DEHP-induced attenuation of TCDD toxicities is due to that DEHP can prevent TCDD to induce Fgf21 expression. As expected, DEHP attenuated TCDD-induced Fgf21 expression in both mouse liver and WAT (Fig. 5). Therefore, pretreatment of mice with DEHP decreases the expression of Fgf21, consequently attenuates the TCDD-produced Fgf21 induction, and therefore decreases TCDD-induced wasting.

Previous studies show that DEHP is a PPARa ligand (Ward et al., 1998). In addition, it is well established that Fgf21 is a target gene of PPARa activation in the liver (Badman et al., 2007; Inagaki et al., 2007; Lundasen et al., 2007). Thus, DEHP should theoretically induce Fgf21 expression in mouse liver. However, our studies showed that DEHP decreased Fgf21 mRNA expression in mouse liver (the top panel of Fig. 5). There is a lack of understanding of the interaction of DEHP with Fgf21/FGF21 promoter and the attenuation of TCDD toxicities by DEHP. Therefore, the specific role of Fgf21 in mediating these actions merit further investigation.

Taken together, the present study showed that activation of AhR by TCDD induced Fgf21 expression. Moreover, induction of Fgf21 by TCDD plays a protective effect. DEHP pretreatment attenuated TCDD-induced Fgf21 expression in mouse liver and white adipose tissue.

\section{Acknowledgments}

We appreciate Dr. Karl K. Rozman for his helpful discussions and suggestions. We thank the people in Dr. Klaassen's laboratory for their help with sample processing and comments on the manuscript.

This work was supported by St. John's University Start funds (to X.C.) and National Institutes of Health grants DK081461, ES09649, and ES019487 (to C.D.K.).

\section{Abbreviation}

$\begin{array}{ll}\text { AhR } & \text { aryl hydrocarbon receptor } \\ \text { Arnt } & \text { aryl hydrocarbon receptor nuclear translocator } \\ \text { bDNA } & \text { branched DNA signal amplification assay } \\ \text { BNF } & \beta \text {-naphthoflavone } \\ \text { ChIP } & \text { chromatin immunoprecipitation }\end{array}$




$\begin{array}{ll}\text { Cyp } & \text { cytochrome p450 enzyme } \\ \text { DEHP } & \text { diethylhexylphthalate } \\ \text { Fgf21 } & \text { fibroblast growth factor } 21 \\ \text { PGC1a } & \text { peroxisome proliferator-activated receptor gamma coactivator protein-1alpha } \\ \text { PPAR } & \text { peroxisome proliferator-activated receptor } \\ \text { RLU } & \text { relative light units } \\ \text { TCDD } & 2,3,7,8 \text {-tetrachlorodibenzo-p-dioxin } \\ \text { WAT } & \text { white adipose tissue } \\ \text { WT } & \text { Wild-type mice } \\ \text { DRE } & \text { dioxin response element }\end{array}$

\section{References}

Adams AC, Coskun T, Cheng CC, LSOF, Dubois SL, Kharitonenkov A. Fibroblast growth factor 21 is not required for the antidiabetic actions of the thiazoladinediones. Mol Metab. 2013; 2:205-214. [PubMed: 24049735]

Adams AC, Kharitonenkov A. FGF21: The center of a transcriptional nexus in metabolic regulation. Curr Diabetes Rev. 2012; 8:285-293. [PubMed: 22587513]

Amakura Y, Tsutsumi T, Sasaki K, Nakamura M, Yoshida T, Maitani T. Influence of food polyphenols on aryl hydrocarbon receptor-signaling pathway estimated by in vitro bioassay. Phytochemistry. 2008; 69:3117-3130. [PubMed: 17869316]

Anwar-Mohamed A, El-Kadi AO. Sulforaphane induces CYP1A1 mRNA, protein, and catalytic activity levels via an AhR-dependent pathway in murine hepatoma Hepa 1c1c7 and human HepG2 cells. Cancer Lett. 2009; 275:93-101. [PubMed: 19013013]

Badman MK, Pissios P, Kennedy AR, Koukos G, Flier JS, Maratos-Flier E. Hepatic fibroblast growth factor 21 is regulated by PPARalpha and is a key mediator of hepatic lipid metabolism in ketotic states. Cell Metab. 2007; 5:426-437. [PubMed: 17550778]

Beenken A, Mohammadi M. The FGF family: biology, pathophysiology and therapy. Nature reviews Drug discovery. 2009; 8:235-253.

Berglund ED, Li CY, Bina HA, Lynes SE, Michael MD, Shanafelt AB, Kharitonenkov A, Wasserman DH. Fibroblast growth factor 21 controls glycemia via regulation of hepatic glucose flux and insulin sensitivity. Endocrinology. 2009; 150:4084-4093. [PubMed: 19470704]

Cheng X, Maher J, Dieter MZ, Klaassen CD. Regulation of mouse organic anion-transporting polypeptides (Oatps) in liver by prototypical microsomal enzyme inducers that activate distinct transcription factor pathways. Drug Metab Dispos. 2005; 33:1276-1282. [PubMed: 15919853]

Croutch CR, Lebofsky M, Schramm KW, Terranova PF, Rozman KK. 2,3,7,8-Tetrachlorodibenzo-pdioxin (TCDD) and 1,2,3,4,7,8-hexachlorodibenzo-p-dioxin (HxCDD) alter body weight by decreasing insulin-like growth factor I (IGF-I) signaling. Toxicol Sci. 2005; 85:560-571. [PubMed: 15703265]

Ding X, Lichti K, Kim I, Gonzalez FJ, Staudinger JL. Regulation of constitutive androstane receptor and its target genes by fasting, cAMP, hepatocyte nuclear factor alpha, and the coactivator peroxisome proliferator-activated receptor gamma coactivator-1alpha. J Biol Chem. 2006; 281:26540-26551. [PubMed: 16825189]

Fon Tacer K, Bookout AL, Ding X, Kurosu H, John GB, Wang L, Goetz R, Mohammadi M, Kuro-o M, Mangelsdorf DJ, Kliewer SA. Research resource: Comprehensive expression atlas of the fibroblast growth factor system in adult mouse. Mol Endocrinol. 2010; 24:2050-2064. [PubMed: 20667984] 
Fried KW, Schneider CM, Schramm KW, Datta A, Chahbane N, Corsten C, Powell DR, Lenoir D, Kettrup A, Terranova P, Georg GI, Rozman KK. From dioxin to drug lead--the development of 2,3,7,8-tetrachlorophenothiazine. Chem Med Chem. 2007; 2:890-897. [PubMed: 17394264]

Galman C, Lundasen T, Kharitonenkov A, Bina HA, Eriksson M, Hafstrom I, Dahlin M, Amark P, Angelin B, Rudling M. The circulating metabolic regulator FGF21 is induced by prolonged fasting and PPARalpha activation in man. Cell Metab. 2008; 8:169-174. [PubMed: 18680716]

IARC. Polychlorinated Dibenzo-para-dioxins and Polychlorinated Dibenzofurans. Vol. 69. International Agency for Research on Cancer; 1997. IARC Monographs on the Evaluation of Carcinogenic Risks to Humans.

Inagaki T, Dutchak P, Zhao G, Ding X, Gautron L, Parameswara V, Li Y, Goetz R, Mohammadi M, Esser V, Elmquist JK, Gerard RD, Burgess SC, Hammer RE, Mangelsdorf DJ, Kliewer SA. Endocrine regulation of the fasting response by PPARalpha-mediated induction of fibroblast growth factor 21. Cell Metab. 2007; 5:415-425. [PubMed: 17550777]

Inagaki T, Lin VY, Goetz R, Mohammadi M, Mangelsdorf DJ, Kliewer SA. Inhibition of growth hormone signaling by the fasting-induced hormone FGF21. Cell Metab. 2008; 8:77-83. [PubMed: 18585098]

Izumiya Y, Bina HA, Ouchi N, Akasaki Y, Kharitonenkov A, Walsh K. FGF21 is an Akt-regulated myokine. FEBS Lett. 2008; 582:3805-3810. [PubMed: 18948104]

Kharitonenkov A, Shiyanova TL, Koester A, Ford AM, Micanovic R, Galbreath EJ, Sandusky GE, Hammond LJ, Moyers JS, Owens RA, Gromada J, Brozinick JT, Hawkins ED, Wroblewski VJ, Li DS, Mehrbod F, Jaskunas SR, Shanafelt AB. FGF-21 as a novel metabolic regulator. J Clin Invest. 2005; 115:1627-1635. [PubMed: 15902306]

Kharitonenkov A, Wroblewski VJ, Koester A, Chen YF, Clutinger CK, Tigno XT, Hansen BC, Shanafelt AB, Etgen GJ. The metabolic state of diabetic monkeys is regulated by fibroblast growth factor-21. Endocrinology. 2007; 148:774-781. [PubMed: 17068132]

Kociba RJ, Keyes DG, Beyer JE, Carreon RM, Wade CE, Dittenber DA, Kalnins RP, Frauson LE, Park CN, Barnard SD, Hummel RA, Humiston CG. Results of a two-year chronic toxicity and oncogenicity study of 2,3,7,8-tetrachlorodibenzo-p-dioxin in rats. Toxicol Appl Pharmacol. 1978; 46:279-303. [PubMed: 734660]

Lakshman MR, Ghosh P, Chirtel SJ. Mechanism of action of 2,3,7,8-tetrachlorodibenzo-p-dioxin on intermediary metabolism in the rat. J Pharmacol Exp Ther. 1991; 258:317-319. [PubMed: 2072303]

Loaiza-Perez AI, Kenney S, Boswell J, Hollingshead M, Alley MC, Hose C, Ciolino HP, Yeh GC, Trepel JB, Vistica DT, Sausville EA. Aryl hydrocarbon receptor activation of an antitumor aminoflavone: basis of selective toxicity for MCF-7 breast tumor cells. Mol Cancer Ther. 2004; 3:715-725. [PubMed: 15210858]

Lundasen T, Hunt MC, Nilsson LM, Sanyal S, Angelin B, Alexson SE, Rudling M. PPARalpha is a key regulator of hepatic FGF21. Biochem Biophys Res Commun. 2007; 360:437-440. [PubMed: 17601491]

McLane KE, Whitlock JP Jr. DNA sequence requirements for Ah receptor/Arnt recognition determined by in vitro transcription. Receptor. 1994; 4:209-222. [PubMed: 7894337]

Moyers JS, Shiyanova TL, Mehrbod F, Dunbar JD, Noblitt TW, Otto KA, Reifel-Miller A, Kharitonenkov A. Molecular determinants of FGF-21 activity-synergy and cross-talk with PPARgamma signaling. J Cell Physiol. 2007; 210:1-6. [PubMed: 17063460]

Muise ES, Azzolina B, Kuo DW, El-Sherbeini M, Tan Y, Yuan X, Mu J, Thompson JR, Berger JP, Wong KK. Adipose fibroblast growth factor 21 is up-regulated by peroxisome proliferatoractivated receptor gamma and altered metabolic states. Mol Pharmacol. 2008; 74:403-412. [PubMed: 18467542]

Nishimura T, Nakatake Y, Konishi M, Itoh N. Identification of a novel FGF, FGF-21, preferentially expressed in the liver. Biochim Biophys Acta. 2000; 1492:203-206. [PubMed: 10858549]

Petrick JS, Klaassen CD. Importance of hepatic induction of constitutive androstane receptor and other transcription factors that regulate xenobiotic metabolism and transport. Drug Metab Dispos. 2007; 35:1806-1815. [PubMed: 17627975] 
Potthoff MJ, Inagaki T, Satapati S, Ding X, He T, Goetz R, Mohammadi M, Finck BN, Mangelsdorf DJ, Kliewer SA, Burgess SC. FGF21 induces PGC-1 $\{$ alpha $\}$ and regulates carbohydrate and fatty acid metabolism during the adaptive starvation response. Proc Natl Acad Sci U S A. 2009; 106:10853-10858. [PubMed: 19541642]

Schmidt JV, Su GH, Reddy JK, Simon MC, Bradfield CA. Characterization of a murine Ahr null allele: involvement of the Ah receptor in hepatic growth and development. Proc Natl Acad Sci U S A. 1996; 93:6731-6736. [PubMed: 8692887]

Suzuki M, Uehara Y, Motomura-Matsuzaka K, Oki J, Koyama Y, Kimura M, Asada M, KomiKuramochi A, Oka S, Imamura T. betaKlotho is required for fibroblast growth factor (FGF) 21 signaling through FGF receptor (FGFR) 1c and FGFR3c. Mol Endocrinol. 2008; 22:1006-1014. [PubMed: 18187602]

Tijet N, Boutros PC, Moffat ID, Okey AB, Tuomisto J, Pohjanvirta R. Aryl hydrocarbon receptor regulates distinct dioxin-dependent and dioxin-independent gene batteries. Mol Pharmacol. 2006; 69:140-153. [PubMed: 16214954]

Tomaszewski KE, Montgomery CA, Melnick RL. Modulation of 2,3,7,8-tetrachlorodibenzo-p-dioxin toxicity in F344 rats by di(2-ethylhexyl)phthalate. Chem Biol Interact. 1988; 65:205-222. [PubMed: 3378278]

Wang H, Qiang L, Farmer SR. Identification of a domain within peroxisome proliferator-activated receptor gamma regulating expression of a group of genes containing fibroblast growth factor 21 that are selectively repressed by SIRT1 in adipocytes. Mol Cell Biol. 2008; 28:188-200. [PubMed: 17954559]

Ward JM, Peters JM, Perella CM, Gonzalez FJ. Receptor and nonreceptor-mediated organ-specific toxicity of di(2-ethylhexyl)phthalate (DEHP) in peroxisome proliferator-activated receptor alphanull mice. Toxicol Pathol. 1998; 26:240-246. [PubMed: 9547862]

Wente W, Efanov AM, Brenner M, Kharitonenkov A, Koster A, Sandusky GE, Sewing S, Treinies I, Zitzer H, Gromada J. Fibroblast growth factor-21 improves pancreatic beta-cell function and survival by activation of extracellular signal-regulated kinase 1/2 and Akt signaling pathways. Diabetes. 2006; 55:2470-2478. [PubMed: 16936195]

Whitlock JP Jr. Genetic and molecular aspects of 2,3,7,8-tetrachlorodibenzo-p-dioxin action. Annu Rev Pharmacol Toxicol. 1990; 30:251-277. [PubMed: 2188570]

Xu J, Stanislaus S, Chinookoswong N, Lau YY, Hager T, Patel J, Ge H, Weiszmann J, Lu SC, Graham M, Busby J, Hecht R, Li YS, Li Y, Lindberg R, Veniant MM. Acute glucose-lowering and insulinsensitizing action of FGF21 in insulin-resistant mouse models--association with liver and adipose tissue effects. Am J Physiol Endocrinol Metab. 2009; 297:E1105-1114. [PubMed: 19706786] 


\section{Highlights}

- TCDD induced Fgf21 expression at both mRNA and protein levels.

- Fgf21 induction by TCDD is AhR-dependent.

- DEHP attenuated TCDD-induced Fgf21 expression. 

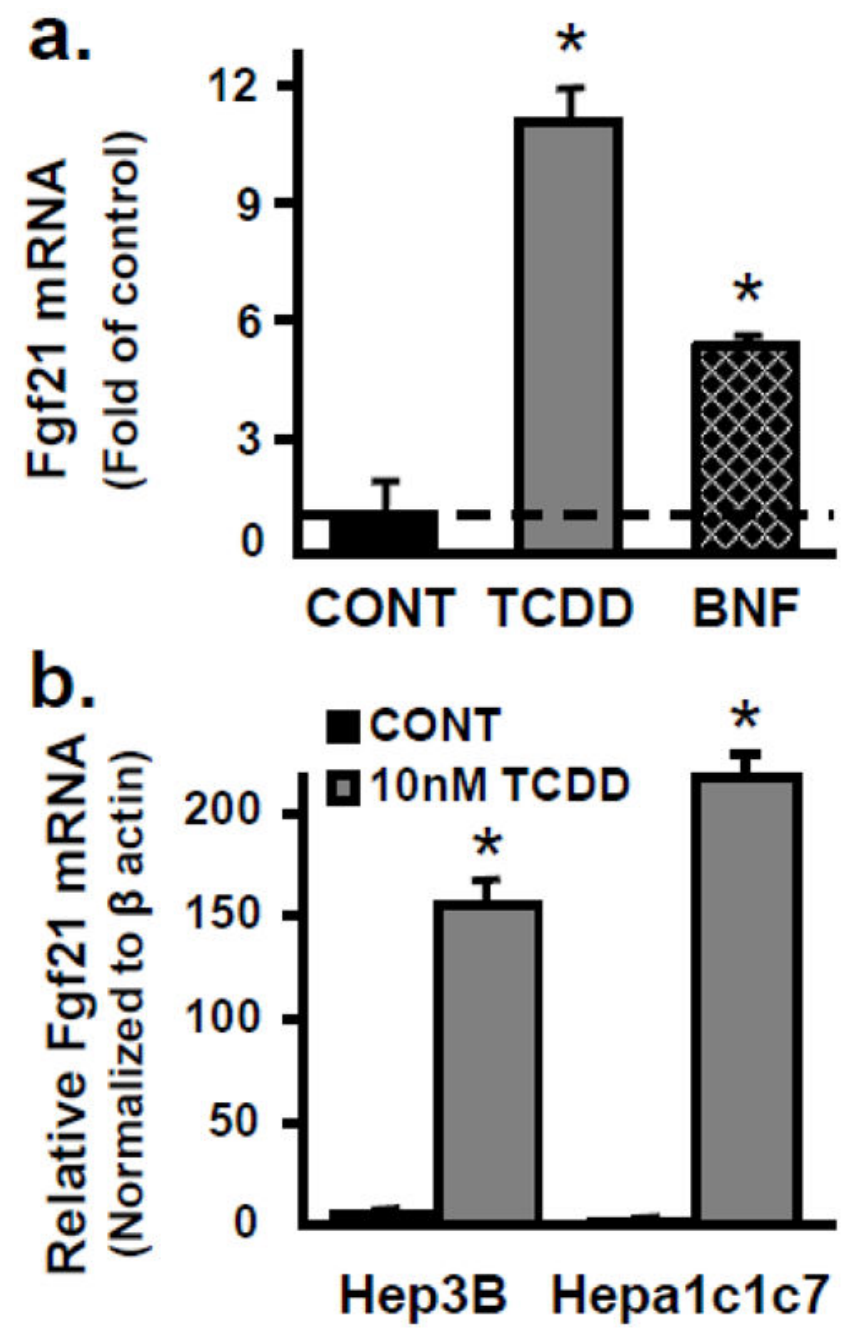

Fig. 1. Regulation of Fgf 21 mRNA expression by AhR ligands

Top panel, Fgf2 1 mRNA in C57BL/6 mouse liver after administration of TCDD (40 $\mu \mathrm{g} / \mathrm{kg})$ and BNF (200 mg/kg) for four consecutive days. Total RNA from mouse livers was analyzed by the bDNA assay. All data are expressed as mean \pm S.E. for five animals in each group, which were combined from the two individual controls after it was determined that they were not statistically different; Bottom panel, Fgf 21 mRNA regulation in human Hep3B and mouse Hepa1c1c7 hepatocytes by 10nM TCDD after 16 hours treatment. All data are expressed as mean \pm S.E. for three samples in each group. Asterisk indicates statistical difference between treated and control (DMSO) $(\mathrm{p}<0.05)$. 


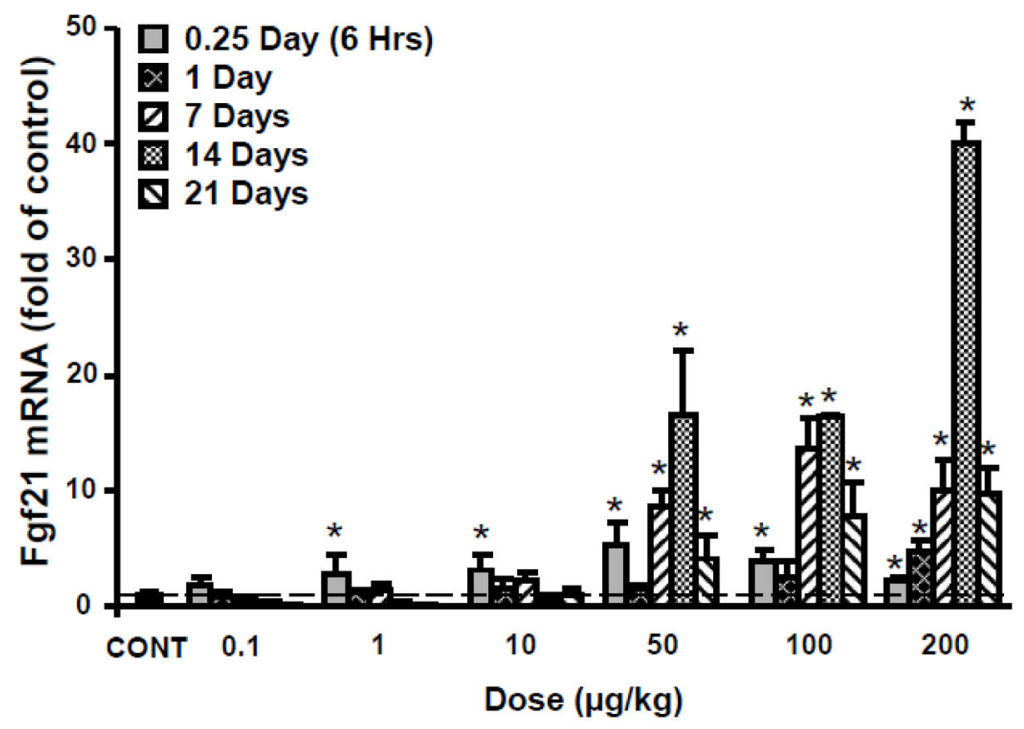

Fig. 2. Dose- and time-dependent regulation of Fgf21 mRNA by TCDD in C57BL/6 mouse liver Adult male WT mice ( $\mathrm{n}=3 /$ treatment/time) were given a single ip administration of TCDD at doses of $0,0.1,1,10,50,100$, or $200 \mu \mathrm{g} / \mathrm{kg}$. After 0.25 (6 hrs), 1, 7, 14, and 21 day(s), the livers were collected. Total RNA was extracted from mouse livers and analyzed by the bDNA assay. All data are expressed as mean \pm S.E. ( $n=3 /$ treatment/time). 


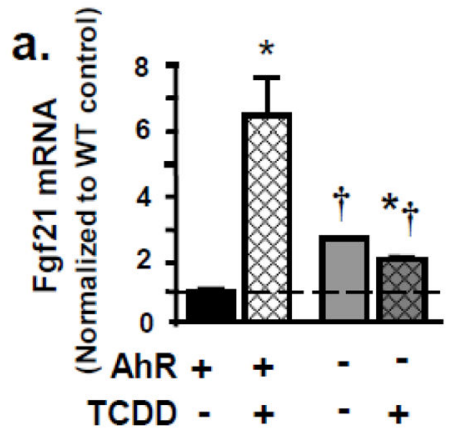

b.

Fgf21 protein
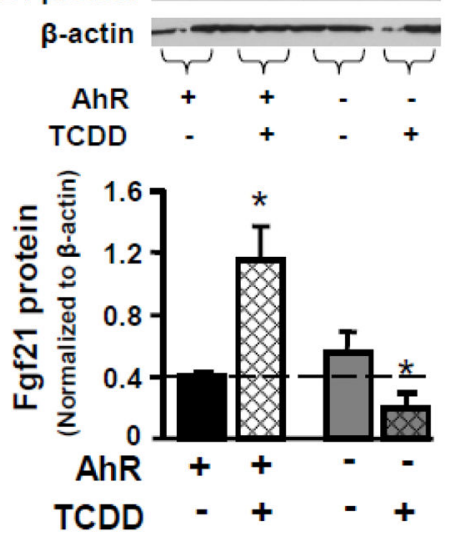

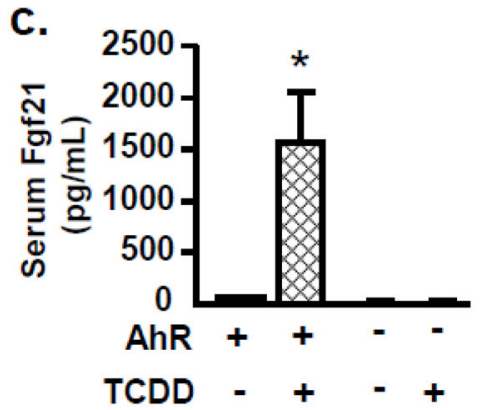

d.

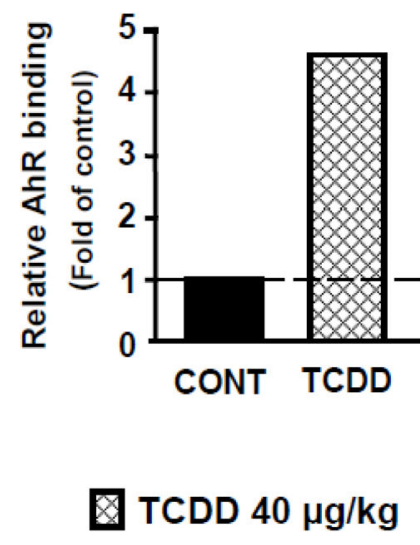

Fig. 3. Effects of TCDD on Fgf21 expression in wild-type and AhR-null mice 3a, Effects of TCDD ( $40 \mu \mathrm{g} / \mathrm{kg})$ on Fgf $21 \mathrm{mRNA}$ expression in mouse liver; 3b, Effects of TCDD $(40 \mu \mathrm{g} / \mathrm{kg})$ on Fgf21 protein expression in mouse livers (Top panel, protein levels of Fgf21 and beta-actin in mouse liver were analyzed by Western blotting; Bottom panel, protein levels of Fgf21 in mouse liver are expressed as the ratio of Fgf 21 to $\beta$-actin protein levels); 3c, Effects of TCDD (40 $\mu \mathrm{g} / \mathrm{kg}$ ) on serum Fgf21 protein concentrations in wild-type and AhR-null mice. 3d, ChIP assays of AhR protein binding to the $-105 /+1 \mathrm{bp}$ promoter region of Fgf21 gene after TCDD $(40 \mu \mathrm{g} / \mathrm{kg})$ treatment. All data are expressed as mean \pm S.E. of 5 mice for each treatment. Asterisk indicates statistical difference between TCDDtreated and control mice $(\mathrm{p}<0.05)$. Single dagger $(\dagger)$ represents statistical differences $(\mathrm{p}<$ 0.05 ) between the same-treated wild-type male mice and the same-treated AhR-null male mice. 

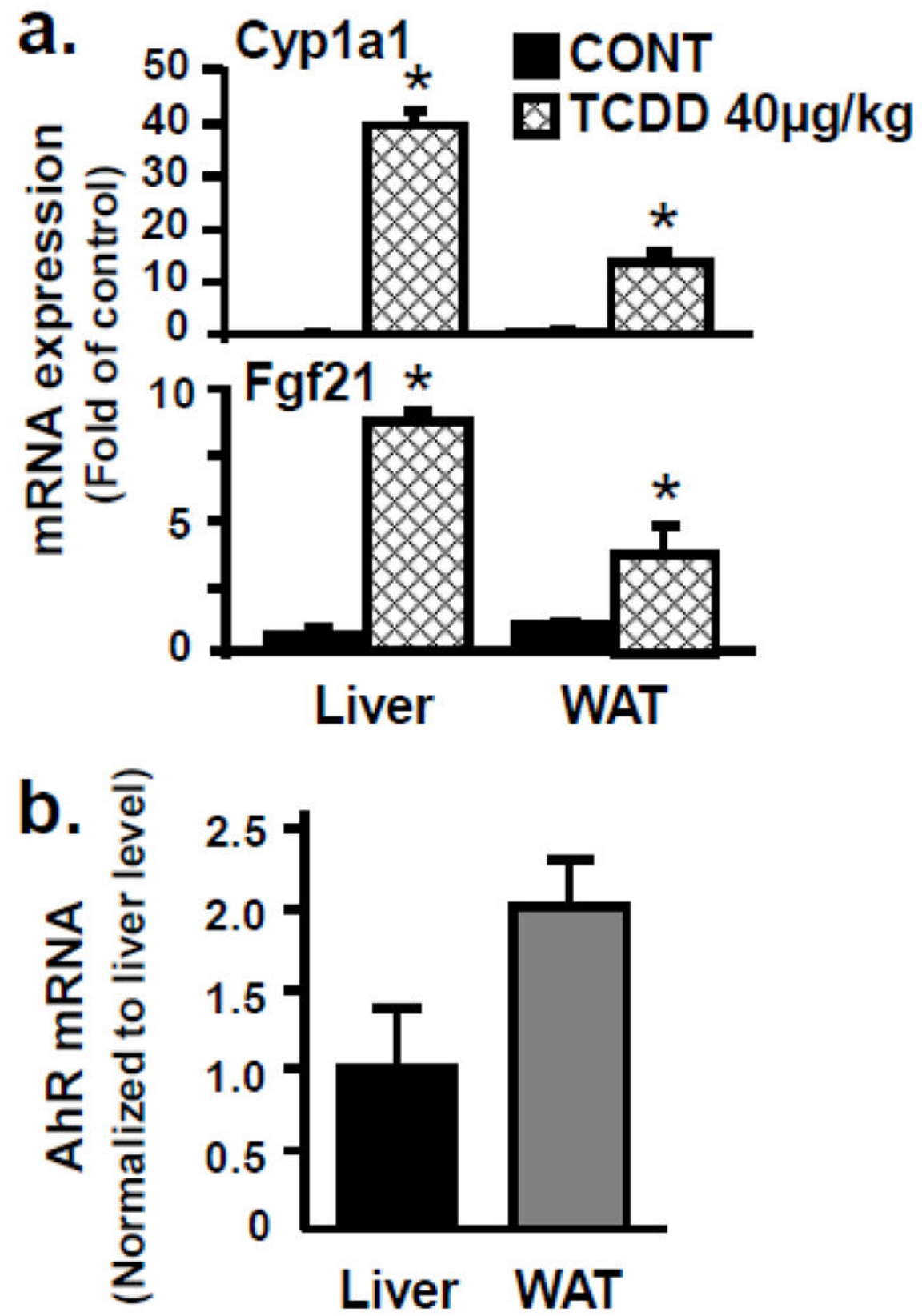

Fig. 4. Regulation of Cyp1a1 and Fgf21 mRNA by TCDD in mouse liver and white adipose tissue (WAT)

Adult male C57BL/6 wild-type mice were treated with corn oil or TCDD $(40 \mu \mathrm{g} / \mathrm{kg})(\mathrm{n}=5 /$ treatment). Total RNA from mouse liver and WAT were analyzed by the bDNA assay. Top panel, regulation of mRNA expression of Cyp1a1 and Fgf21 by TCDD; Bottom panel, constitutive mRNA expression of AhR in mouse liver and WAT. All data were expressed as mean \pm S.E. $(n=4-5$ mice). Asterisk indicates statistical difference between TCDD-treated and control-treated mice $(\mathrm{p}<0.05)$. 


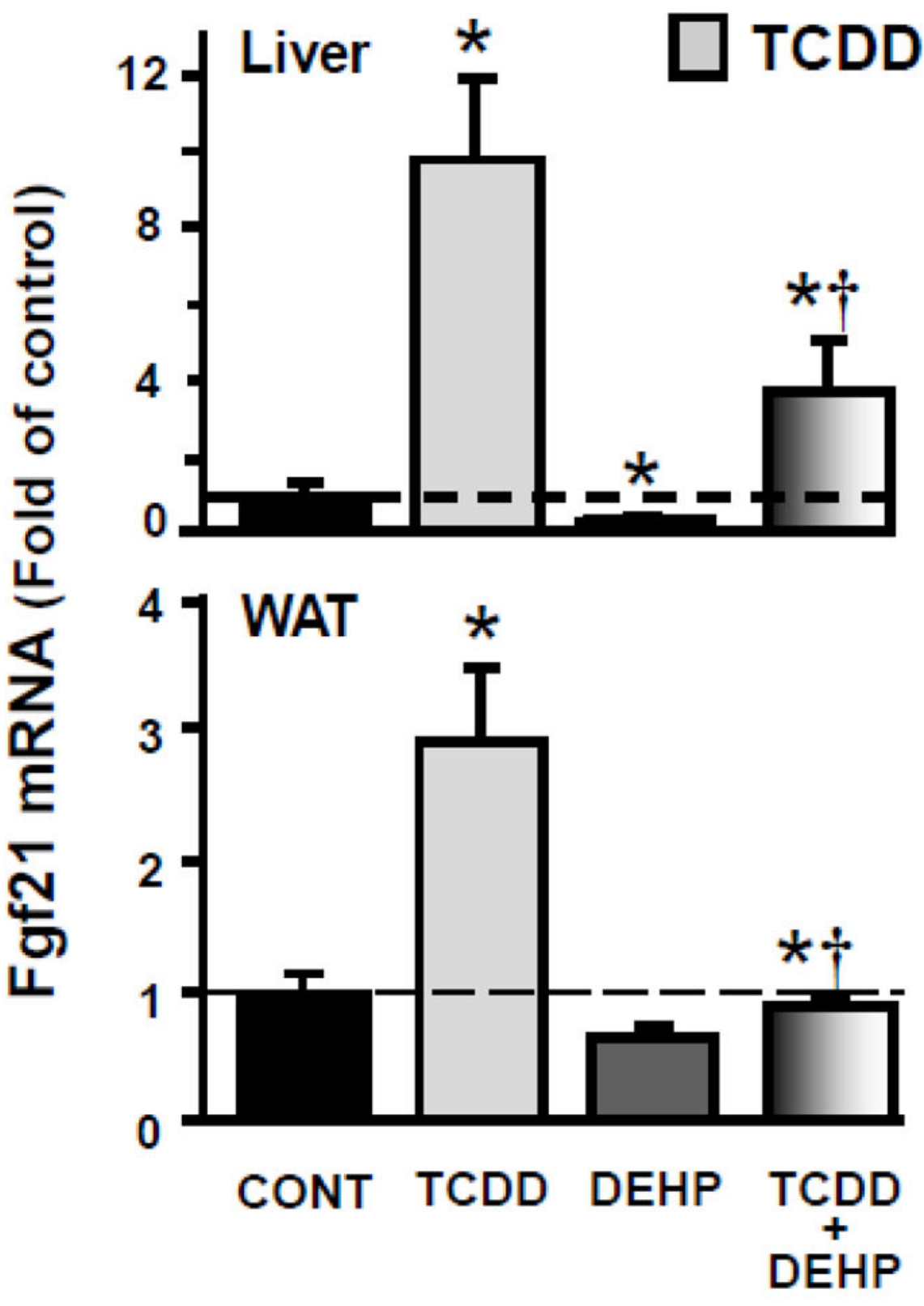

Fig. 5. Diethylhexylphthalate (DEHP) modifies TCDD-induced Fgf21 expression in mouse liver and WAT

Mice were treated with corn oil, TCDD $(40 \mu \mathrm{g} / \mathrm{kg})$, or DEHP $(1000 \mathrm{mg} / \mathrm{kg})(\mathrm{n}=5 / \mathrm{treatment})$. One group of mice $(n=4)$ was pretreated with DEHP; after $24 \mathrm{hrs,} \mathrm{these} \mathrm{mice} \mathrm{were} \mathrm{treated}$ with TCDD. Top panel, The effect of DEHP pretreatment on TCDD-induced Fgf21 expression in mouse liver; Bottom panel, The effect of DEHP pretreatment on TCDDinduced Fgf21 expression in mouse WAT. Total RNA from mouse livers and WAT of each treatment were analyzed by the bDNA assay. All data are expressed as mean \pm S.E. $(n=4-5$ mice). Asterisk indicates statistical difference between TCDD/DEHP-treated and controltreated mice $(\mathrm{p}<0.05)$. Single dagger $(\dagger)$ represent statistical differences $(\mathrm{p}<0.05)$ between TCDD treated group with or without DEHP pretreatment. 

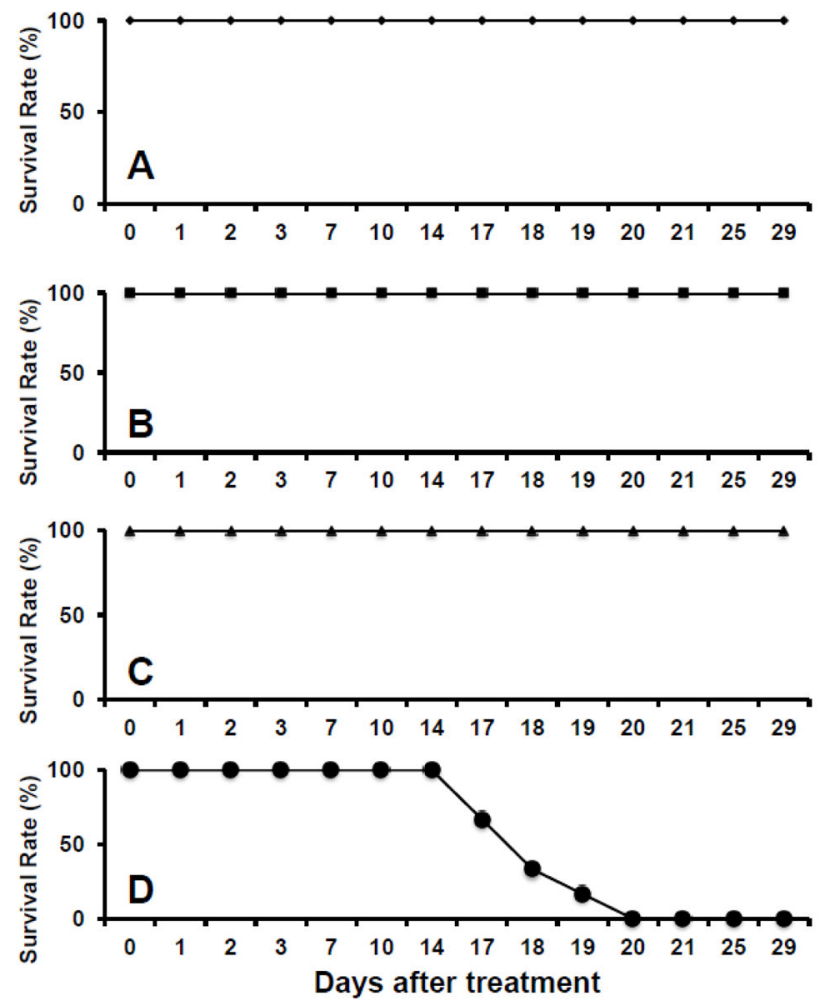

Fig. 6. Fgf21 ameliorates TCDD-induced lethality

Adult (approximately 8-weeks of age) wild-type male mice and age-matched Fgf21-null male mice were given a single ip administration of corn oil or TCDD (200 $\mu \mathrm{g} / \mathrm{kg})(\mathrm{n}=4-7 /$ treatment). A: wild-type mice treated with corn oil $(n=6)$; B: wild-type mice treated with TCDD (n=7); C: Fgf21-null mice treated with corn oil $(n=4)$; and D: Fgf21-null mice treated with TCDD $(n=6)$. Mouse survival was monitored daily. 


\section{Table 1}

Oligonucleotide probes generated for analysis of mouse Fgf21 mRNA expression by bDNA signal amplification assays

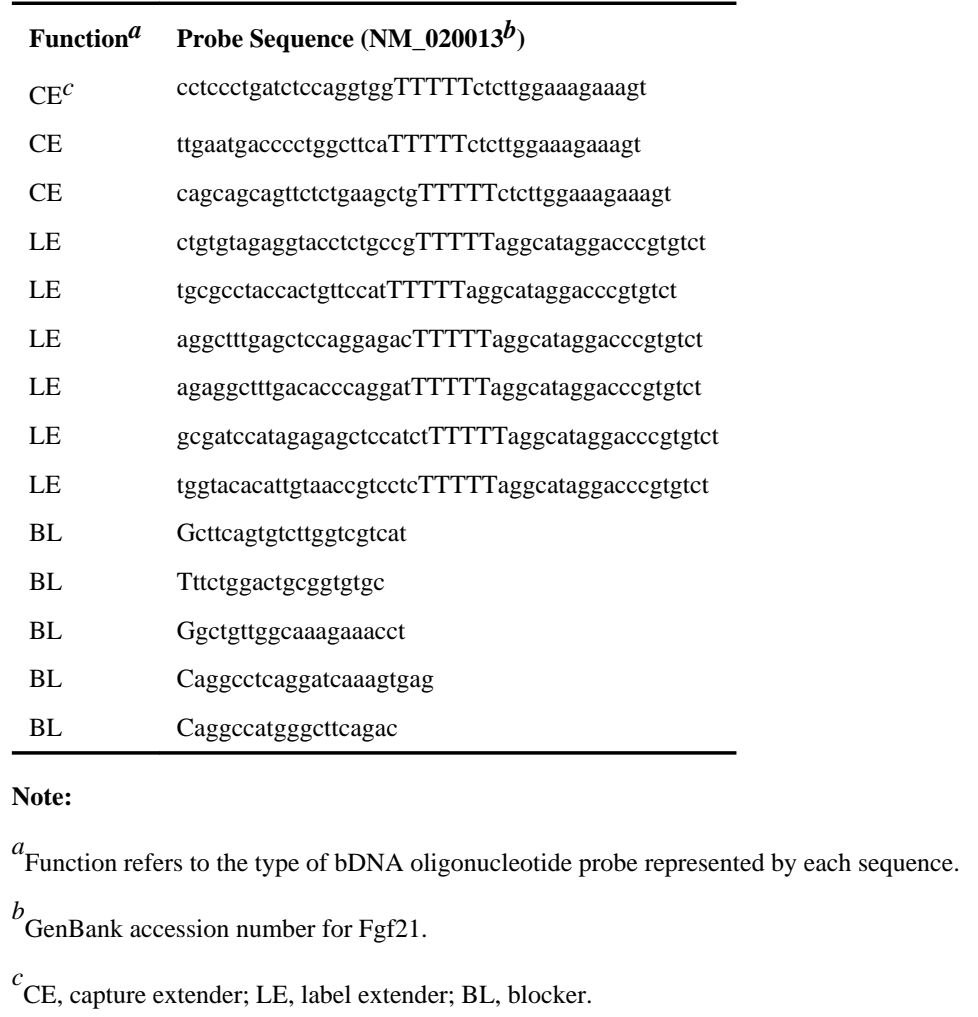

